\title{
XXII. On the determination of chemical affinity in terms of electromotive force-Part VI
}

\section{C.R. Alder Wright D.Sc. F.R.S.}

To cite this article: C.R. Alder Wright D.Sc. F.R.S. (1882) XXII. On the determination of chemical affinity in terms of electromotive force-Part VI, Philosophical Magazine Series 5, 14:87, 188-211, DOI: $10.1080 / 14786448208628427$

To link to this article: http://dx.doi.org/10.1080/14786448208628427

曲 Published online: 28 Apr 2009.

Submit your article to this journal $[\pi$

Џll Article views: 2

Q View related articles $\square$ 
XXII. On the Determination of Chemical Affinity in terms of Electromotive Force.-Part VI. By C. R. AlDER WRIGHT, D.Sc. (Lond.), F.R.S., Lecturer on Chemistry and Physics in St. Mary's Hospital Medical School*.

On the Relations between the Electromotive Forces of various kinds of Cells analogous to Daniell's Cell lut differing therefrom in the nature of the Metals used, and the Chemical Affinities involved in the Action of these Cells.

I. Cells containing Cadmium as one of the Metals, the Salts used being Sulphates.

118. THE experiments described in Part V. ( $\$ 106-109)$ 1 were repeated, using, instead of normal Daniell cells, analogous arrangements containing plates of cadmium, opposed in some instances to copper, in others to zinc, solutions of the respective sulphates being employed to surround the various plates used. With each of these two classes of cells (cadmium-copper and zinc-cadmium cells) the same result was obtained as that already recorded in the case of Daniell cells containing zinc- and copper-sulphate solutionsviz. that so long as the two solutions are of the same strength $\dagger$ the actual state of concentration of the fluids does not exert any appreciable influence on the E.M.F. generated with given plate-surfaces; at least the influence exerted is considerably less than the errors of observation and the variations due to unaroidable variations in the nature of the plate-surfaces, and does not amount to as much as \pm .0015 volt even

* Communicated by the Physical Society, having been read at the Meeting on Jume 24, 1882.

$\dagger$ It is convenient to define solutions "of the same strength" not as solutions of the kind usually spoken of by chemists as "equivalent" to one another, i. e. containing in a given volume quantities of dissolved matter in the ratio of the chemical equivalents of the substances dissolved (e.g. 159.5, 161, and 208 parts of anhydrous copper, zinc, and cadmium sulphate respectively), but as solutions in which the dissolved matter and the water present are in the same molecular ratio, i. e. which are expressible by parallel formulæ, such as $\mathrm{CuSO}_{4} 50 \mathrm{H}_{2} \mathrm{O}, \mathrm{ZnSO}_{4} 50 \mathrm{H}_{2} \mathrm{O}$, and $\mathrm{CdSO}_{4} 50 \mathrm{H}_{2} \mathrm{O}$. With weak solutions the two definitions are practically the same-but not so with more concentrated Huids, especially when the molecular weights of the dissolved matters are considerably different (like $\mathrm{CuSO}_{4}$ and $\mathrm{CdSO}_{4}$ ). Solutions of zinc and copper sulphate of the same molecular strength are practically identical in specific gravity ; but a solution of cadmium sulphate is considerably more dense than one of either zinc or copper sulphate of the same molecular strength. Thus solutions of the strengths $\mathrm{ZnSO}_{4} 50 \mathrm{II}_{2} \mathrm{O}, \mathrm{CuSO}_{4} 50 \mathrm{H}_{2} \mathrm{O}, \mathrm{CdSO}_{4} 50 \mathrm{H}_{2} \mathrm{O}$ have at $18^{\circ}$ specific gravities respectively close to $1 \cdot 170,1 \cdot 167$, and 1.208 ; with stronger solutions the excess of density of the cadmium solution is still more apparent. 
when tolerably concentrated solutions of strength $\mathrm{MSO}_{4}$ $50 \mathrm{H}_{2} \mathrm{O}$ are compared with similar solutions of only one twenty-fifth the strength, $\mathrm{MSO}_{4} 1250 \mathrm{H}_{2} \mathrm{O}$.

On varying the nature of the surface of the cadmium plate (by employing bright cast metal, electro-deposited cadmium, or amalgamated cadmium), it was found that whatever result was produced in the cadmium-copper cells by a given alteration of the cadmium plate, every thing else remaining unaltered, precisely the same numerical result, lut with the opposite sign, was produced in the zinc-cadnium cells by that alteration. Thus, substituting electro-cadmium for bright cadmium plates in the cadmium-copper cells caused an increctse in the E.M.F. varying from $\cdot 002$ to $\cdot 006$ volt in numerous experiments, and averaging $\cdot 004$ rolt; whilst with the zinc-cadmium cells the same substitution caused a decrease in the E.M.F. varying between almost the same limits, $\cdot 002$ and $\cdot 007$ volt, and averaging almost the same ralue as before, riz. $\cdot 0045$ volt. Similarly, ou substituting amalgamated cidmiun plates for bright cadmium in the cadmium-copper cells, the arerage effect was a decrease of 0415 volt when the mercurial amalgam was fluid, and of 015 volt when it had become solid and crystalline on standing; whilst with the zinc-cadmium cells, substitution for bright cadmium of amalgamated metal caused on an average an increase in E.M.F. of 043 volt when the amalgam was fluid, and of $\cdot 016$ volt when it had become solid and crystalline.

\section{Cells containing Cadminim opposed to Copper.}

119. On comparing together a number of similar pairs of cells containing in the one case electro-copper and in the other amalgamated copper, it was found that the average difference was sensibly the same as that obscrved when the same two kinds of copper plates were opposed to zine ( $\$ 107)$, viz. that, cceteris paribus, the cell containing amalgamated copper read on an average $\cdot 001$ volt lower than the one containing freshly deposited electro-copper: the actually observed differences ranged from +.003 to -.003 volt, but were more usually negative.

- As just stated, when the cadmium plate was amalgamated a decrease in E.M.F. was bronght about, averaging 0415 volt when the amalgam on the surface of the plate was fresh and perfectly fluid, and 015 when perfectly solid and crystalline. Intermediate mumbers were given by plates on the surface of which crystallization of the amalgam had begun but was not complete, the gradation being regular as the crrstallization progressed. 
The following table gives the average result, in volts*, of upwards of forty series of observations and comparisons, mostly extending over three to four hours, during which time the readings of each particular cell remained sensibly constant:-

Variation in E.M.F. due to the use of cadmium and copper sulphate solutions of different strengths, both solutions being of equal Less than molecular strengths in any given case $\pm^{\circ} 0015$. (strengths varying from $\mathrm{MSO}_{4} 47 \mathrm{H}_{2} \mathrm{O}$, to $\left.\mathrm{MSO}_{4} 1250 \mathrm{H}_{2} \mathrm{O}\right) \dagger$.

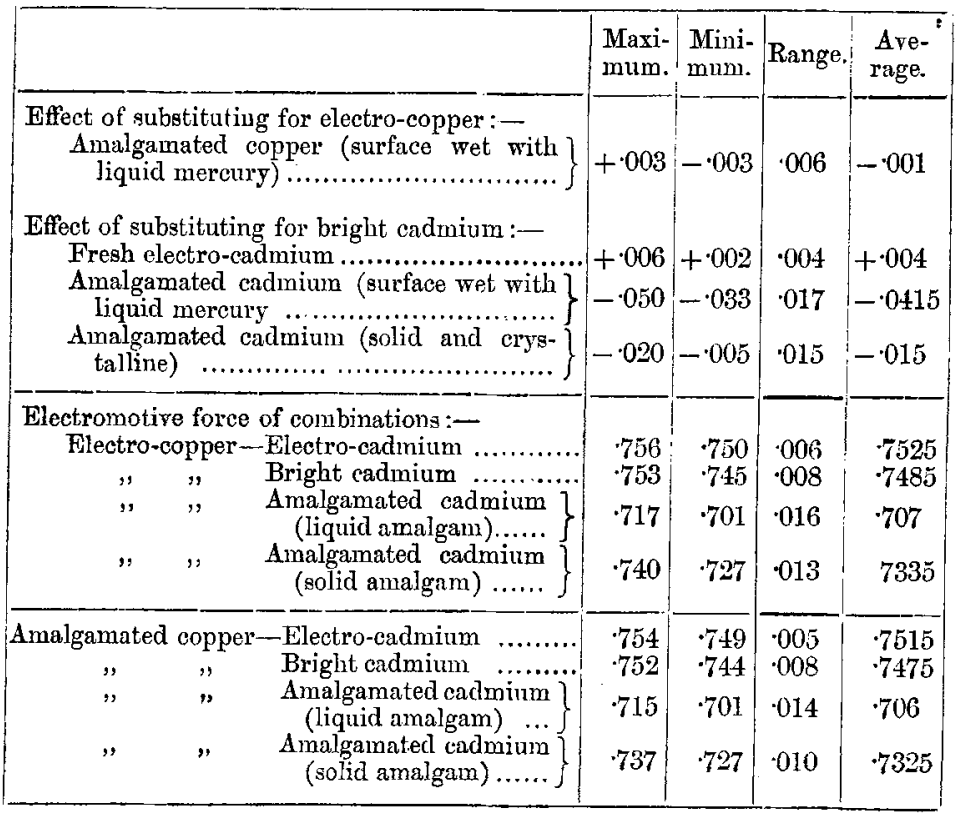

When cells containing bright or electro-cadmium and electro-copper plates were allowed to stand for twelve hours or

* All the olsservations given in this paper are reduced to the same standard as that employed in Part V.-viz. the average reading at $15^{\circ} .5$ of a number of Clark's cells taken as 1.457 volt, the particular Clark's cells used being the same throughout.

$\uparrow$ The specific gravities at about $19^{\circ}$ of these fluids are close to the following:-

$\mathrm{MSO}_{4} 47 \mathrm{H}_{2} \mathrm{O}$ when $\mathrm{M}[$ is cadmium : spec. grav. $=1 \cdot 217$.

do. when $\mathrm{M}$ is copper: spec. grav. $=1 \cdot 175$; solution

$\mathrm{MSO}_{\frac{4}{4}} 1250 \mathrm{H}_{2} \mathrm{O}$; in each case below 1.01 . nearly saturated. 
longer periods, a slight alteration in the E.M.F., due to formation of films of oxide on the surfaces of the plates, was usually noticeable. As with the normal Daniells ( $\$ 108$ ), the effect of the oxidation of the copper plate was to reduce the E.M.F. by a few thousandths of a volt; on the other hand, the formation of a film of oxide on the surface of the cadmium plate produced an increase in the E.M.F. of from 001 to 004 volt; so that in many cases the cell with partially oxidized plates gave sensibly the same value as a newly set-up cell, the diminishing effect of the oxidation of the copper being just about counterbalanced by the increasing effect due to the oxidation of the cadmium. In this respect cadmium behaves in the opposite way to zine $(\$ 108)$.

\section{Relations between the E.M.F. of Cadmium-Copper Cells and that conresponding to the net Chemical Action taking place therein.}

120. According to Julius Thomsen's determinations (Joumn. prak. Chem. ii. p. 233, and xi. p. 271), the heat of displacement of copper from copper-sulphate solution $\left(\mathrm{CuSO}_{4}, 400 \mathrm{H}_{2} \mathrm{O}\right)$ by cadmium is as follows, in gramme-degrees per grammemolecule:-

$$
\begin{array}{r}
\mathrm{Cd}, \mathrm{O}, \mathrm{SO}_{3} \mathrm{aq} . \\
\mathrm{Cu}, \mathrm{O}, \mathrm{SO}_{3} \text { aq. } \\
\text { Difference }
\end{array}
$$

the difference corresponding to 16,770 gramme-clegrees per granme equivalent, or $\cdot 740$ volt*. As with normal Daniell cells $(\$ 114)$, a small quantity $(x)$ is to be added to this, representing a variable correction dependent on the physical condition of the deposited copper. Evidently the average values above cited $(\cdot 7475$ to $\cdot 7525)$, obtained with bright and electrocadmium, are sensibly the same as the value $\cdot 740+a$, thus deduced as representing the net chemical action taking place in the cell; i. e., as with zinc-copper cells, the whole of the energy developed in the cell is adjuvant under the conditions obtaining in the above experiments.

In order to compare the results obtained with the amalgamated-cadmium cells with Julius Thomsen's figures, the heat of solution of cadmium (precipitated from the sulphate by zinc, crystalline) in twenty-five times its weight of mercury was determined by means of the calorimeter, 20 grams of

* The value 4410, used in the former parts of these researches for the factor for converting gramme-degrees into C.G.S. tmits, is emploved throughout the present paper: vide $\$ 103$, footnote. 
cadmium and 500 of pure mercury being employed for each experiment. To insure solution it was found necessary to wash the cadmium with dilute sulphuric acid just before use; otherwise portions remained unwetted and undissolved by the mercury. The final result arrived at as the average of several concordant observations was, that an evolution of heat to the extent of 610 gramme-degrees per gramme-molecule (112 grammes) of cadmium took place during solution. Hence, were cadmium sulphate formed from mercurial solution of metal instead of crystalline precipitated metal, the heat of formation expressed as $\mathrm{Cd}, \mathrm{O}, \mathrm{SO}_{3}$ aq. would be $89,500-610=$ 88,890 (admitting that Thomsen's value 89,500 applies, without correction, to the metal in the erystalline condition of that experimented with). Consequently the heat of displacement of copper by cadmium from the sulphate is 32,930 per grammemolecule, or 16,465 per gramme-equivalent, corresponding to .726 volt. The observed values varied between $\cdot 701$ and $\cdot 717$, averaging $\cdot 707$ with electro-copper and $\cdot 706$ with amalgamated copper-again not differing from the value deduced from the thermal data by an amount materially outside the limits of experimental errors, especially, those due to variation in the heat of formation of salts according as the physical state of the metal employed varies.

It is, however, to be noticed that the above heat of solution of crystalline cadmium in mercury only corresponds to an E.M.F. of $\cdot 0135$ volt; whilst the average difference in E.M.F. caused by the substitution of fluid amalgamated cadmium for crystalline electro-metal was $\cdot 7525-\cdot 707=\cdot 0455$ volt, a considerably greater amount; so that amalgamating the crystalline metal appears to produce a greater effect on the E.M.F. than corresponds to the heat of solution. Just the same result is produced when cadmium and zinc are opposed $(\$ 121)$; on the other hand, the effect on the E.M.F. of amal gamating silver is sensibly the same as that corresponding to the heat of solution of silver in mercury $(\$ 129)$. Probably the difference in the cases of silver and cadmium is due to the oxidizability of the latter by dissolved air, thus rendering the onter surface of the crystalline masses somewhat different from the interior.

\section{Cells contuining Cadmium opposed to Zinc.}

121. The following table exhibits in brief the results of upwards of thirty series of observations, mostly lasting over several hours, during which period the E.M.F. developed by any given cell remained sensibly steady :- 
Variation in E.M.F. due to the use of cad-? mium and zinc sulphate solutions of different strengths, both solutions being of equal molecular strengths in any given case (strengths \pm \pm 0015 cular strengths in any given case (strengths
varying from $\mathrm{MSO}_{4} 50 \mathrm{H}_{2} \mathrm{O}$ to $\mathrm{MSO}_{4}$
$\left.1250 \mathrm{H}_{2} \mathrm{O}\right)$

\begin{tabular}{|c|c|c|c|c|c|c|}
\hline & & & $\begin{array}{l}\text { Maxi- } \\
\text { mum. }\end{array}$ & $\begin{array}{l}\text { Mini- } \\
\text { mum. }\end{array}$ & Range. & $\begin{array}{l}\text { Ave- } \\
\text { rage. }\end{array}$ \\
\hline $\begin{array}{l}\text { Effect of su } \\
\text { Fresh e }\end{array}$ & ati & - bright cadmium :- & & & & \\
\hline Amalga & 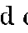 & m (liquid) & +.052 & +.036 & .016 & $\begin{array}{l}-0045 \\
+.044\end{array}$ \\
\hline , & & (solid, crystalline) & +.024 & $+\cdot 009$ & $\cdot 015$ & +0165 \\
\hline Electromoti & $c e$ & mbinations:- & & & & \\
\hline Amalga & & Bright cadmium ...... & 367 & 361 & .006 & $\cdot 364$ \\
\hline ", & & Electro-cadmium ... & $\cdot 362$ & $\cdot 358$ & .004 & -360 \\
\hline ", & " & $\begin{array}{c}\text { Awalgamated cad- } \\
\text { mium (liquid)... }\end{array}$ & $\cdot 414$ & 401 & $\cdot 013$ & $\cdot 4075$ \\
\hline " & 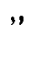 & $\left.\begin{array}{c}\text { Ama]gamated cad- } \\
\text { mium (solid) ... }\end{array}\right\}$ & 388 & $\cdot 373$ & 015 & $\cdot 3805$ \\
\hline
\end{tabular}

These figures accord closely with the results deducible from Julius Thomsen's thermochemical data, together with the heat of solution of cadmium in mercury above quoted ( $(120)$; thus:-

Free metallic cadmium.

\begin{tabular}{|c|c|c|c|}
\hline $\begin{array}{l}\mathrm{Zn}, \mathrm{O}, \mathrm{SO}_{3} \mathrm{aq} . \\
\mathrm{Cd}, \mathrm{O}, \mathrm{SO}_{3} \mathrm{aq} .\end{array}$ & $\begin{array}{l}\cdot . \\
\cdot .\end{array}$ & $\begin{array}{r}106090 \\
89500\end{array}$ & $\begin{array}{c}\text { in mercury } \\
106090 \\
88890\end{array}$ \\
\hline Difference & . . & 16590 & 17200 \\
\hline $\begin{array}{c}\text { Difference per gra } \\
\text { equivalent. }\end{array}$ & mme- $\}$ & 8295 & 8600 \\
\hline Corresponding wi & $h$ volt & $\cdot 365$ & $\cdot 379$ \\
\hline
\end{tabular}

The observed electromotive forces* thus do not differ from

* Regnault has shown (Ann. de Chim. et de Phys. [3] xliv. p. 453) that the E.M.F. of a cell containing "concentrated" solutions of zinc and cadmium sulphates and plates of these metals was 55, when that of a similar cell with zinc and copper sulphates and plates was 175 (a particuiar thermopile being employed as unit). Taking the E.M.F. of the latter cell as 1.115 volt, that of the former must have been $\cdot 350$ volt-a value differing from those observed by an amount not outside that possibly due to inequality in the molecular strengths of the two metallic solutions. For, by the use of more dilute cadmium-sulphate solutions (the zincsulphate solution remaining the same) an appreciable fall in E.M.F. was found to be produced, the lowest value being $42=268$ volt with solution diluted to $\frac{1}{100}$; on the other hand, decreasing the strength of the zincsulphate solution produced far less effect. These and the author's somewhat different results on this point will be discussed in a future paper.

Phil. Mag. S. 5. Vol. 14. No. 87. Sept. 1882. 
those corresponding with the thermal values by amounts materially outside the experimental errors. As with the coppercadmium cells, however, the observed difference in E.M.F. between electro-cadmium (crystalline) and amalgamated cadmium (liquid) is notably greater than that corresponding with the heat of solution of precipitated crystalline cadmium in mercury, being $\cdot 407-\cdot 3595=\cdot 0475$ as compared with $\cdot 0135$ volt.

\section{Volta's Law of Summation of Electromotive Forces.}

122. The foregoing experiments clearly show that, as far as cells containing zinc, cadmium, and copper plates are concerned, Volta's law of summation holds, at any rate when the plates are immersed in solutions of their respective sulphates, the solutions being of equal molecular strength; that is, the sum of the electromotive forces generated with a given pair of zinc and cadmium plates, and with that same cadmium plate and a given copper plate, is equal to the E.M.F. generated with the given zinc and copper plates; or, otherwise,

$$
\left\{\begin{array}{l}
\mathrm{Zn} \\
\mathrm{Cd}
\end{array}+\left\{\begin{array}{l}
\mathrm{Cd} \\
\mathrm{Cu}
\end{array}=\left\{\begin{array}{l}
\mathrm{Zn} \\
\mathrm{Cu}
\end{array}\right.\right.\right.
$$

where the symbol $\left\{\begin{array}{l}\mathrm{Zn} \\ \mathrm{Cd}\end{array}\right.$ represents the E.M.F. generated with a given kind of zinc plate opposed to a given kind of cadmium plate, each plate being immersed in a solution of its sulphate of constant molecular strength.

Thus the average results for Daniell cells quoted in PartV. and the above figures give the following comparisons:-

\begin{tabular}{|c|c|c|c|c|c|c|}
\hline \multicolumn{3}{|c|}{ Nature of Plate-surfaces. } & \multicolumn{3}{|c|}{$\begin{array}{c}\text { Electromotive Force } \\
\text { developed. }\end{array}$} & \multirow{2}{*}{$\begin{array}{l}\text { Normal } \\
\text { Daniell. }\end{array}$} \\
\hline Zinc. & Oadmium. & Copper. & $\begin{array}{c}\text { Zinc- } \\
\text { Cadmium. }\end{array}$ & $\left|\begin{array}{c}\text { Cadmium- } \\
\text { copper. }\end{array}\right|$ & Sum. & \\
\hline $\begin{array}{c}\text { Amalgamated. } \\
" \\
" \\
"\end{array}$ & $\begin{array}{c}\text { Electro. } \\
\text { Bright. } \\
\text { Amalgamated } \\
\text { (fluid). } \\
\text { Amalgamated } \\
\text { (golid). }\end{array}$ & $\begin{array}{c}\text { Electro. } \\
\quad ", \\
, "\end{array}$ & $\begin{array}{l}\cdot 3595 \\
\cdot 364 \\
\cdot 407 \\
\cdot 380\end{array}$ & $\begin{array}{c}.7525 \\
.7485 \\
.707 \\
.7335 \\
\text { Mean ... }\end{array}$ & \begin{tabular}{|l|}
$1 \cdot 112$ \\
$1 \cdot 1125$ \\
$1 \cdot 114$ \\
$1 \cdot 1135$ \\
$1 \cdot 1130$
\end{tabular} & $\begin{array}{c}\text { Amalga- } \\
\text { mated zinc } \\
\text { and electro- } \\
\text { copper } 1111 \\
\text { to } 1 \cdot 116 \\
\text { averaging } \\
1 \cdot 114 \text {. }\end{array}$ \\
\hline $\begin{array}{c}\text { Amalgamated. } \\
" \\
" \\
"\end{array}$ & $\begin{array}{c}\text { Electro. } \\
\text { Bright. } \\
\text { Amalgamated } \\
\text { (finid). } \\
\text { Amalgamated } \\
\text { (solid). }\end{array}$ & $\begin{array}{c}\text { Amalgamated. } \\
",\end{array}$ & $\begin{array}{l}\cdot 3595 \\
\cdot 364 \\
\cdot 407 \\
\\
\cdot 380\end{array}$ & $\begin{array}{c}7515 \\
.7475 \\
.706 \\
.7325 \\
\text { Mean } \ldots\end{array}$ & $\left|\begin{array}{l}1 \cdot 111 \\
1 \cdot 1115 \\
1 \cdot 113 \\
1 \cdot 1125 \\
1 \cdot 1120\end{array}\right|$ & $\begin{array}{c}\text { Amalga- } \\
\text { mated zinc } \\
\text { and amalga- } \\
\text { mated cop- } \\
\text { per } 1 \cdot 110 \\
\text { to } 1 \cdot 115 \text {, } \\
\text { averaging } \\
1 \cdot 113 \text {. }\end{array}$ \\
\hline
\end{tabular}


A number of direct experiments were also made on this point, using twin cells constructed as follows:-Three beakers were arranged containing solutions of copper, cadmium, and zinc sulphates of the same molecular strengths, and plates of electro-copper, bright (or electro-) cadmium, and amalgamated zinc respectively. The copper and cadmium beakers were connected by a siphon tube (with ends covered with bladder) filled with the cadmium sulphate solution; and the cadmium and zinc beakers were similarly connected by a siphon tube containing the zinc sulphate solution. The copper, cadmium, and zinc plates were then connected with cups Nos. 1, 2, and 3 respectively of a switch-board like that represented in fig. 3, Part V. $(\S 106)$; so that by connecting cups 1 and 2 with the electrometer the E.M.F. of the cadmiumcopper cell was determined, whilst when cups 2 and 3 were connected the E.M.F. of the cadmium-zinc combination was determined. These readings having been made several times, the zino and copper plates were transferred to another pair of beakers, containing the same zinc and copper sulphate solutions united by a zinc-sulphate siphon, so as to constitute a normal Daniell cell after Raoult's pattern, and the E.M.F. of this combination determined. Several pairs of zinc and copper plates were thus used-each pair being read first in the zinc-cadmium-copper combination, then in the normal Daniell cell, and then again in the ternary combination. In each case the difference between the sum of the average electromotive forces of the zinc-cadmium and cadmium-copper couples differed from that of the zinc-copper combination by quantities no greater than the errors of observation of the electrometerscale (about $\pm 0 \cdot 1$ per cent. when a sufficient number of readings were taken); whilst the average of the small differences observed with different pairs was actually 0 , the small + and - differences due to errors of observation completely balancing one another. This final result (that no discernible difference was to be found between the sum of zinc-cadmium and cadmium-copper couples, and zinc-copper couples containing the same plates) was obtained in each of several sets of experiments made respectively with solutions of molecular strength $\mathrm{MSO}_{4} 47 \mathrm{H}_{2} \mathrm{O}, \mathrm{MSO}_{4} 100 \mathrm{H}_{2} \mathrm{O}$, and $\mathrm{MSO}_{4} 1250 \mathrm{H}_{2} \mathrm{O}$.

\section{Rate of Fall in E.M.F.through so-called Polarization occurring in Zinc-Cadmium and Cadmium-Copper Cells for definite amounts of Increase in the Rates of Current-flow.}

123. The experiments made with normal Daniell cells described in Part V. ( $\$ \$ 103-105)$ were repeated with zinccadmium and with cadmium-copper plates (exposing surfaces 
of 2.5 and 5.0 square centimetres). The results were similar in character to those obtained with the Daniell cells, no appreciable falling-off in E.M.F. occurring with a currentdensity of less than some 5 to 10 microampères per square centimetre of plate-surface, but very considerable amounts being observed with stronger currents.

Thus the following table exhibits the values obtained in four experiments-the first three with zinc-cadmium plates, the fourth with cadmium-copper plates, solutions of sulphates of the respective metals employed being used throughout:-

\begin{tabular}{|c|c|c|c|c|}
\hline $\begin{array}{l}\text { Zine plates } . . . . . . . \\
\text { Oadmium plates ... } \\
\text { Copper plates ...... }\end{array}$ & $\begin{array}{c}\text { Amalgamated. } \\
\text { Electro } \\
\ldots \ldots\end{array}$ & $\begin{array}{c}\text { Amalgamated. } \\
\text { Amalgamated. } \\
\text { Fluid amalgam. } \\
\ldots . . . . . .\end{array}$ & $\begin{array}{c}\text { Amalgamated. } \\
\text { Amalgamated. } \\
\text { Solid amalgain. } \\
\text {.......... }\end{array}$ & $\begin{array}{l}\text { Bright. } \\
\text { Electro. }\end{array}$ \\
\hline $\left.\begin{array}{r}\text { Sp. gr. of zinc sul- } \\
\text { phate solution... } \\
\text { Sp. gr. of cadmium } \\
\text { sulphate solntion } \\
\text { Sp. gr. of copper } \\
\text { sulphate solution }\end{array}\right\}$ & $\cdots \cdots$ & $\cdots \cdots$ & ...... & $\begin{array}{l}\cdots \cdots \\
1 \cdot 32 \\
1 \cdot 17\end{array}$ \\
\hline $\left.\begin{array}{c}\text { Resistance of cell, } \\
\text { in ohms } \ldots \ldots \ldots . . \\
\text { MaximumE.M.F., } \\
\text { in volts } \ldots \ldots \ldots . .\end{array}\right\}$ & $\begin{array}{l}9 \cdot 5 \\
\cdot 366\end{array}$ & $\begin{array}{l}10 \cdot 5 \\
\cdot 418\end{array}$ & $\begin{array}{l}11 \cdot 0 \\
395\end{array}$ & $\begin{array}{l}7 \cdot 4 \\
\cdot 741\end{array}$ \\
\hline $\begin{array}{l}\text { Current-density, in } \\
\text { microampères per } \\
\text { square centimetre. }\end{array}$ & \multicolumn{4}{|c|}{ Observed amounts of Fall in E.M.F. } \\
\hline $\begin{array}{r}10 \\
20 \\
40 \\
100 \\
200 \\
400 \\
1000 \\
2000 \\
4000\end{array}$ & $\begin{array}{c}0 \\
0 \\
.001 \\
.002 \\
.004 \\
.012 \\
.026 \\
.049 \\
.088\end{array}$ & $\begin{array}{c}0 \\
.001 \\
.002 \\
.004 \\
.007 \\
.013 \\
.030 \\
.059 \\
.099\end{array}$ & $\begin{array}{c}0 \\
\cdot 001 \\
\cdot 003 \\
.007 \\
\cdot 011 \\
.017 \\
\cdot 030 \\
\cdot 055 \\
\cdot 094\end{array}$ & $\begin{array}{r}.001 \\
.004 \\
.008 \\
.014 \\
.020 \\
.030 \\
.049 \\
.077 \\
\cdot 128\end{array}$ \\
\hline
\end{tabular}

The values are represented graphically by the curves marked I., II., III., and IV. respectively in the annexed figure.

A number of experiments were made with cells containing solutions not of equal molecular strengths (like those described in $\$ 110$ ), for the purpose of finding how much of the diminutions observed with the larger current-densities might possibly be due to the strengthening of the solution round the dissolved plate, and the weakening of the liquid round the other plate, which takes place whilst the cell is in action. The general result was that the maximum possible diminution due to these causes could not exceed about 04 volt. The 
Chemical Affinity in terms of Electromotive Force.

details of these experiments and of others allied thereto will be discussed in a future paper.

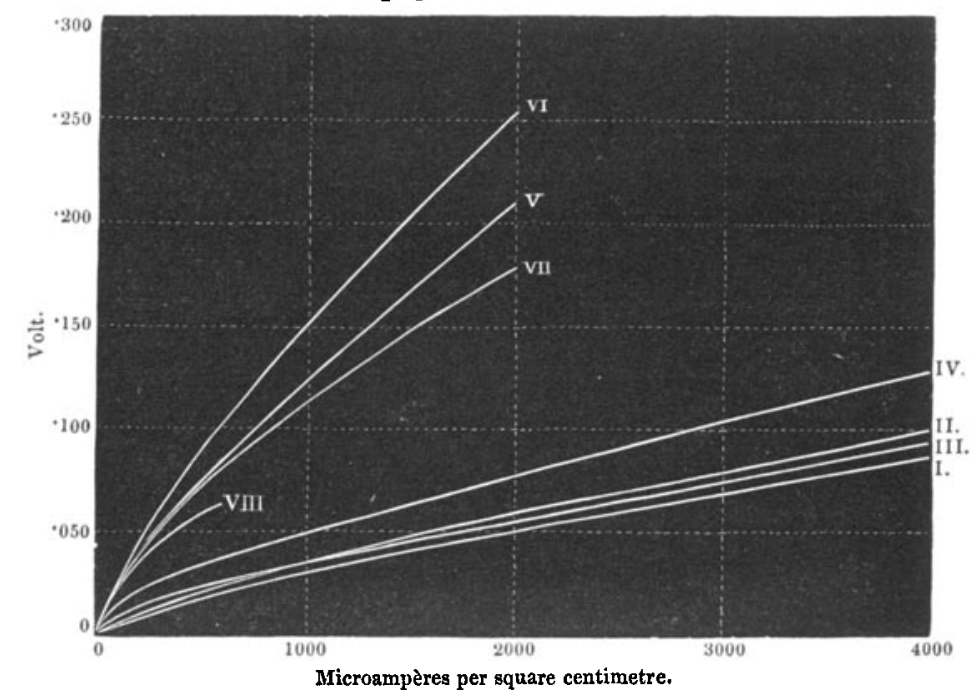

Effect of varying the Size of one of the Plates, the other remaining constant.

124. The experiments described in Part V. $(\$ 115)$ were repeated with various cells containing copper-cadmium or zinc-cadmium plates instead of zinc-copper ones. The following values obtained in four such experiments illustrate the results obtained, indicating that the effect of halving the area of the plate on which metal is deposited is, as with the Daniell cells, greater than the effect of halving the area of the dissolved plate, when the former plate is not mercurialized*. The zinccadmium cells, however, differ from ordinary Daniell cells in this respect-that, whilst amalgamating the copper plate of a Daniell cell does not materially alter the relative effect of halving its area, amalgamating the cadmium plate of a zinccadmium cell greatly diminishes the relative effect of halving its area, in such sort that, when solid crystalline amalgam is used, the effect of halving the area of the cadmium plates, instead of exceeding, becomes sensibly equal to the effect of halving the area of the zinc plate, whilst when liquid amal-

* It is noteworthy in this connexion, that when nearly pure wroughtiron plates, immersed in ferrous sulphate solution, replace the zinc plates and zinc sulphate solution of normal Daniell cells, the effect of halving the area of the iron plates sometimes exceeds that produced by halving the area of the copper plates 
gam is used the effect of halving the area of the cadmium plate becomes sensibly less than the effect of halving that of the zinc plate.

\begin{tabular}{|c|c|c|c|c|c|c|c|c|}
\hline \multirow{4}{*}{$\begin{array}{l}\text { Current, } \\
\text { in micro- } \\
\text { amperes. }\end{array}$} & \multirow{2}{*}{\multicolumn{2}{|c|}{ 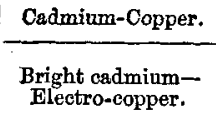 }} & \multicolumn{6}{|c|}{ Zino-Cadminm. } \\
\hline & & & \multirow{2}{*}{\multicolumn{2}{|c|}{$\frac{\begin{array}{c}\text { Amalgamated zinc- } \\
\text { Electro-cadmium. }\end{array}}{\begin{array}{c}\text { Effeot of halving } \\
\text { area of }\end{array}}$}} & \multirow{2}{*}{\multicolumn{2}{|c|}{$\begin{array}{l}\begin{array}{c}\text { Amalgamated zino- } \\
\text { Fluid amalgamated } \\
\text { cadmium. }\end{array} \\
\begin{array}{c}\text { Effect of halping } \\
\text { area of }\end{array}\end{array}$}} & \multirow{2}{*}{\multicolumn{2}{|c|}{$\frac{\begin{array}{c}\text { Amalgamated zinc- } \\
\text { Bolid amalgamated } \\
\text { cadmium. }\end{array}}{\begin{array}{c}\text { Effect of halving } \\
\text { area of }\end{array}}$}} \\
\hline & \multicolumn{2}{|c|}{$\begin{array}{l}\text { Effect of halving } \\
\text { area of }\end{array}$} & & & & & & \\
\hline & Cadmium. & Copper. & Zinc. & Crdmium. & Zino. & Cadminm. & Zinc. & Cadmium. \\
\hline 1000 & .005 & .008 & .004 & .005 & .005 & .003 & .005 & .006 \\
\hline 2000 & 010 & .013 & .007 & .008 & 009 & $\cdot 005$ & .011 & .015 \\
\hline 5000 & .016 & .022 & .012 & 013 & .018 & $\cdot 011$ & .021 & .019 \\
\hline 10000 & .020 & 031 & $\cdot 020$ & $\cdot 025$ & $\cdot 027$ & $\cdot 015$ & 026 & .025 \\
\hline 20000 & .039 & .051 & $\cdot 030$ & .040 & .035 & $\cdot 022$ & .032 & .032 \\
\hline
\end{tabular}

\section{Cells containing Silver as one of the Metals, the Salts used being Sulphates.}

125. Three sets of cells, after Raoult's pattern, were constructed, containing respectively zinc-silver, cadmium-silver, and copper-silver couples, the respective plates being immersed in solutions of silver sulphate saturated at ordinary temperatures, and of copper and zinc sulphate of strengths molecularly equal thereto (the silver solution contained $7 \cdot 25$ grammes of $\mathrm{Ag}_{2} \mathrm{SO}_{4}$ per litre, and had a sp. gr. near to 1.0067); the composition was uniformly $\mathrm{MSO}_{4} 2360 \mathrm{H}_{2} \mathrm{O}$.

On making series of determinations of the E.M.F.'s of these cells, the following results were arrived at as the effects of varying the nature of the silver surfaces, deduced from the average values of a large number of observations (upwards of 50 sets of comparisons).

Effect of substituting Electro-Silver for Bright Silver.

Zinc opposed. Cadmium opposed. Copper opposed.

$\begin{array}{lcc}\text { Maximum } \ldots+.017 & +.015 & +.012 \\ \text { Minimum ... }+.003 & +.005 & +.004 \\ \text { Range......... } .014 & .010 & .008 \\ \text { Average...... }+.008 & +.009 & +.0075\end{array}$


Effect of substituting Amalqamated Silver (fluid) for Bright Silver.

$\begin{array}{lcc}\text { Maximum ... }+\cdot 102 & +\cdot 110 & +\cdot 105 \\ \text { Minimum ... }+.092 & +.095 & +.092 \\ \text { Range........ } \cdot 010 & \cdot 015 & .013 \\ \text { Average...... }+.099 & +\cdot 101 & +\cdot 1025\end{array}$

Considering the perceptibly wider ranges of variation in these experiments than those usually observed in the zinccadmium-copper cells proviously described, it is evident that the effect of varying the nature of the silver plate is sensibly independent of the nature of the other metal.

Sometimes, but not invariably, the amalgamated silver plates became solid and crystalline (greenish yellow) on the surface : this result was apparently brought about much more rapidly when the silver was immersed in concentrated zinc sulphato solution than under any other of the conditions obtaining in the various experiments. When this change took place the E.M.F. set up by opposing such a plate to zinc in cells containing sulphates of zinc and silver was always intermediate between that set up in the same fluids by plates of bright silver and of fluid amalgamated silver. The average of several comparisons was as follows :-

Effect of substituting Amalgamated Silver (solid) for Bright Silver.

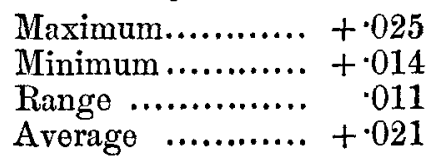

In this respect silver is analogous to cadmium when the latter is opposed to zine ( $\$ 121)$; but the average amounts of increase in E.M.F. due to fluid and solid amalgam are in each instance considerably greater with silver than with cadmium (.099 and $\cdot 021$ for silver as compared with $\cdot 043$ and .016 for cadmium).

On substituting electro-for bright cadmium in the cadmiumsilver cells, identically the same average effect was observed as in the cadmium-copper cells ( $\$ 119)$, viz. an increase in the E.M.F. of from $\cdot 002$ to $\cdot 006$, averaging $\cdot 004$ volt. Similarly, on substituting amalgamated for electro-copper in the copper-silver cells, practically the same numerical difference in the E.M.F. was brought about as was formerly observed in the zinccopper cells $(\$ 107)$ and the cadminm-copper cells $(\$ 119)$, but in the opposite direction, the E.M.F. being ratsed in the 
copper-silver cells and lowered in the other two kinds : the alteration in the E.M.F. varied between $+\cdot 005$ and $-\cdot 003$, averaging $+\cdot 0005$.

126. On allowing newly set-up cells to stand for several hours, different results were brought about in each of the three cases according as the silver was opposed to zinc, cadmium, or copper. In the first case the E.M.F. invariably fell; the maximum value was observed immediately after the cell was set up, and continued sensibly steady for a variable period of time, a distinct diminution becoming perceptible sometimes after half an hour, sometimes only after two or three hours. With cadmium the value after several hours was somewhat greater than that set up at first and during the subsequent hour or so; and with copper the value attained after several hours was still greater than that exhibited during the first hour or two. The following numbers represent the average alterations thus observed, being the differences between the average readings during the first hour and during a period of from 3 to 5 hours after setting up :-

Amalgamated Zinc opposed.

\begin{tabular}{|c|c|c|c|}
\hline $\begin{array}{l}\text { Bright silver. } \\
\quad-.010\end{array}$ & $\begin{array}{l}\text { Electro-silver. } \\
\quad-014\end{array}$ & $\begin{array}{c}\text { Amalgamated silver. } \\
-.012\end{array}$ & $\begin{array}{r}\text { Mean. } \\
-\cdot 012\end{array}$ \\
\hline \multicolumn{4}{|c|}{ Bright Cadmium opposed. } \\
\hline$+\cdot 003$ & $+\cdot 001$ & $+\cdot 003$ & $+\cdot 002$ \\
\hline \multicolumn{4}{|c|}{ Electro-Cadmium opposed. } \\
\hline$+\cdot 003$ & $+\cdot 004$ & $+\cdot 003$ & $+\cdot 003$ \\
\hline \multicolumn{4}{|c|}{ Electro-Copper opposed. } \\
\hline$+\cdot 009$ & $+\cdot 007$ & $+\cdot 007$ & $+\cdot 008$ \\
\hline \multicolumn{4}{|c|}{ Amalgamated Copper opposed. } \\
\hline$+\cdot 011$ & $+\cdot 009$ & +.005 & $+\cdot 008$ \\
\hline
\end{tabular}

These alterations were traced to the variations in the nature of the surfaces of the plates opposed to the silver; for on taking out, for instance, an amalgamated zinc plate after 5 hours, and replacing by a freshly amalgamated plate, the E.M.F. was restored to sensibly the same value as at first; and similarly with the other metals. On the other hand, on taking out from two cells, for instance, a zinc and a copper plate after 5 hours, and replacing them respectively in two beakers containing zinc and copper sulphate solutions of the same molecular strengths, and connected by a siphon tube, the E.M.F. of the cell thus formed was found to fall short of the 
average value of a normal Daniell cell with fresh plates by an amount sensibly equal to the sum of the numerical alterations that had occurred in the zinc-silver and copper-silver cells jointly. It is specially noticeable that, whilst in zinc-copper cells the alteration in the surface of the copper (probably through oxidation) on standing diminishes the E.M.F., in copper-silver cells the alteration is in the opposite direction : with zinc and cadmium the direction of this alteration when opposed to silver is the same as when opposed to copper.

It would seem from all these results that the effect of a given alteration of the surface of one of the plates of a voltaic pair upon the E.M.F. of the pair is independent of the nature of the other plate as regards its numerical value, although the nature of this second plate regulates the direction of the variation in the E.M.F. produced (increase or decrease), and also exerts an influence upon the rate at which the alteration of the platesurface takes place. Thus it was repeatedly observed that, whereas an amalgamated zinc plate (or an electro-copper one), when forming part of a normal Daniell cell, did not become sensibly oxidized, so as to diminish the E.M.F. of the cell, until after several hours at least had elapsed, a precisely similar plate immersed in the same liquid, but forming part of a zincsilver cell (or of a copper-silver cell), did become perceptibly oxidized in much less time. In other words, although no measurable current was generated in either case, yet the different amounts of strain (so to speak) set up in the chain of liquid particles between the two plates, according as one was silver or not, did affect the rate of change in the surface of the more oxidizable metal (presumably by varying the rate at which it combined with the oxygen dissolved in the fluid).

127. The following Table exhibits the average results obtained in about 150 sets of observations and comparisons, only those values made during the first hour (or sometimes less) after setting up being taken into account, and all subsequent values being rejected where any diminution through oxidation $\& c$. began to be perceptible *. The values cited as the average effects of substituting for bright silver electro- and amalgamated (liquid) silver are the means of the three sets above quoted $(\$ 125)$ obtained respectively with zinc, cadmium, and copper :-

* Notwithstanding all care, it is probable that the average results with the zinc-silver cells are too low by a few thousandths of a volt, and those with the other cells slightly too high (vide $\$ 128$ ). 


\begin{tabular}{|c|c|c|c|c|}
\hline & $\begin{array}{l}\text { Maxi- } \\
\text { mum. }\end{array}$ & $\begin{array}{l}\text { Mini- } \\
\text { mum. }\end{array}$ & Range. & Average. \\
\hline Effect of substituting for br & .017 & $+\cdot 003$ & $\cdot 014$ & $+\cdot 008$ \\
\hline 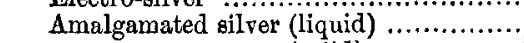 & +100 & $+\cdot 092$ & .008 & 01 \\
\hline$" \quad$ " (8o & $+\cdot 025$ & $+\cdot 014$ & $\cdot 011$ & $+\cdot 021$ \\
\hline $\begin{array}{l}\text { Effect of substituting for electro-copper:- } \\
\text { Amalgamated copper .............................. }\end{array}$ & +.005 & $-\cdot 003$ & $\cdot 008$ & $+\cdot 001$ \\
\hline $\begin{array}{l}\text { uting for bright cadm } \\
\text { nium .................... }\end{array}$ & $+\cdot 006$ & +002 & .004 & $+\cdot 004$ \\
\hline Electromotive & & & & \\
\hline $\operatorname{lga}$ & 1540 & 1.518 & $\cdot 022$ & $1 \cdot 528$ \\
\hline Ele & 1.550 & 1.529 & $\cdot 021$ & 1.536 \\
\hline Amalg.silver(liquid) & $1 \cdot 640$ & $1 \cdot 615$ & .025 & $1 \cdot 627$ \\
\hline Brigh"t cadmin & $\begin{array}{l}1 \cdot 555 \\
1 \cdot 173\end{array}$ & $\begin{array}{l}1 \cdot 544 \\
1 \cdot 163\end{array}$ & $\cdot 011$ & $\frac{49}{675}$ \\
\hline ", & $\begin{array}{l}1.185 \\
1 \cdot 160\end{array}$ & $\begin{array}{l}1.163 \\
1 \cdot 169\end{array}$ & 016 & $1 \cdot 1765$ \\
\hline Am & $1 \cdot 278$ & $1 \cdot 261$ & .017 & 1.2685 \\
\hline Electro-cad̈mium-Br & $1 \cdot 176$ & $1 \cdot 164$ & .012 & $1 \cdot 1715$ \\
\hline Ele & $1 \cdot 186$ & $1 \cdot 176$ & $\cdot 010$ & $1 \cdot 1805$ \\
\hline ver (liquid) & $1 \cdot 277$ & $1 \cdot 267$ & $\cdot 010$ & 1.2725 \\
\hline Electro-copper-Bright silver ............. & .422 & 411 & $\cdot 011$ & 416 \\
\hline$"$ & $\cdot 429$ & -411 & $\cdot 018$ & •4235 \\
\hline$"$ ", Amalg. si & $\cdot 535$ & 513 & 022 & 5185 \\
\hline Amalgamated copper--Bri & $\cdot 420$ & $\cdot 411$ & .009 & $\cdot 4165$ \\
\hline Elec & $\cdot 430$ & $\cdot 414$ & .016 & 424 \\
\hline "Amalg, silver (liquid) & 535 & $\cdot 513$ & .022 & •519 \\
\hline
\end{tabular}

\section{Volta's Law of Summation.}

128. The values in this table, together with those quoted above for the zinc-cadmium and cadmium-copper cells ( $\$ \S$ 119 and 121) and those given in Part V. for zinc-copper cells ( $\$ 107)$, clearly prove that Volta's law holds in the case of the sets of combinations

$$
\begin{aligned}
& \left\{\begin{array}{l}
\mathrm{Zn} \\
\mathrm{Cd}
\end{array}+\left\{\begin{array}{l}
\mathrm{Cd} \\
\mathrm{Ag}
\end{array}=\left\{\begin{array}{l}
\mathrm{Zn} \\
\mathrm{Ag}
\end{array}\right.\right.\right. \\
& \left\{\begin{array}{l}
\mathrm{Zn} \\
\mathrm{Cu}
\end{array}\right. \\
& \left\{\begin{array}{l}
\mathrm{Cd} \\
\mathrm{Cu}
\end{array}+\left\{\begin{array}{l}
\mathrm{Zn} \\
\mathrm{Ag}
\end{array}\right.\right. \\
&
\end{aligned}
$$

at any rate within the range of possible error due to the somewhat larger ranges of fluctuation in the E.M.F. of silvercontaining cells than were observed with zinc-cadmium-copper cells, and to the fact that, although alterations of the oxidizable plates in the cells containing silver was avoided as far as possible by only carrying on the observations for one hour and sometimes less, still it was not practicable wholly to avoid this source of inaccuracy. Thus in the three cases respecvely the following figures are obtained :- 
Chemical Affinity in terms of Electromotive Force. 203

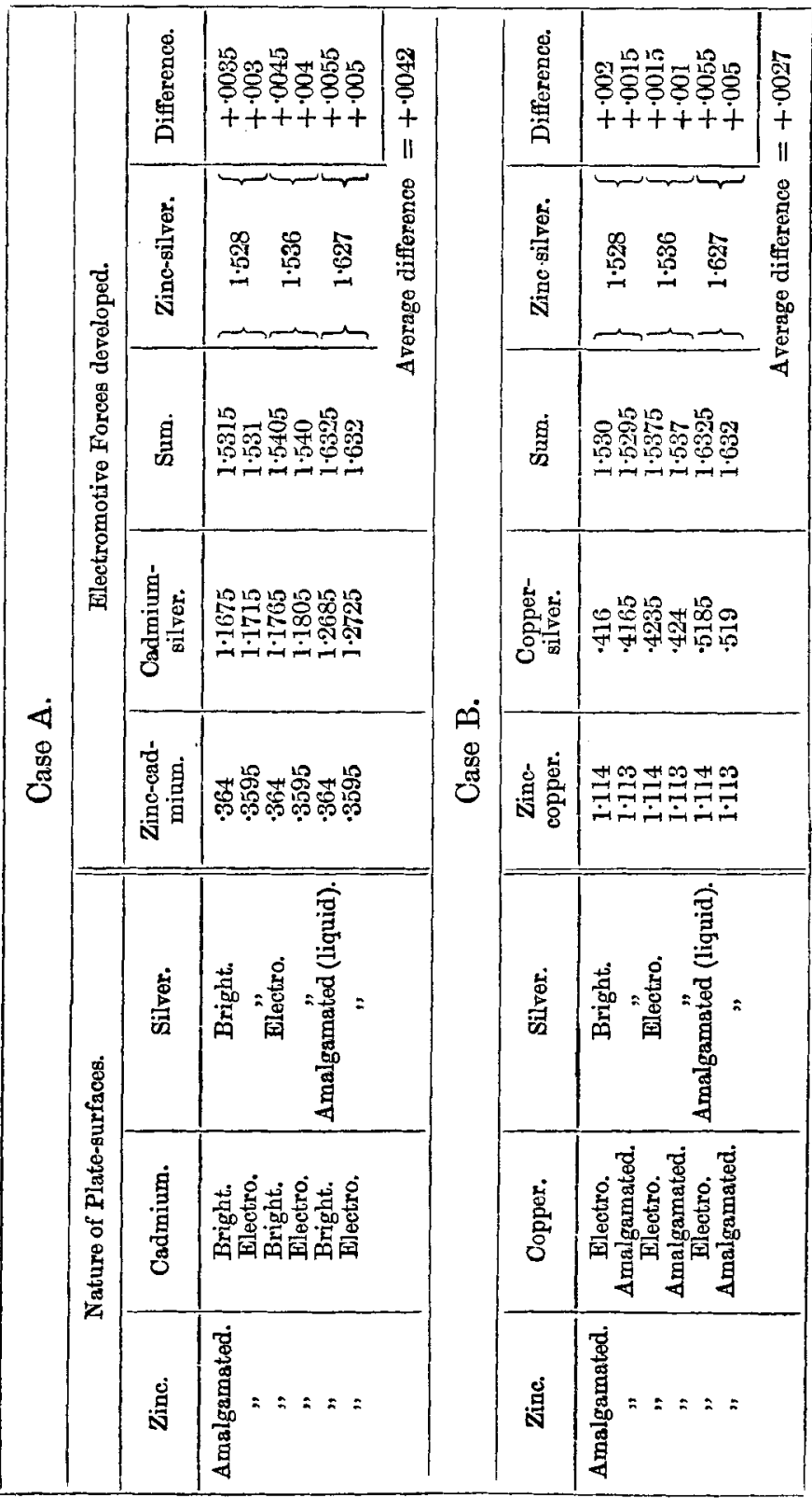


204 Dr. C. R. A. Wright on the Determination of

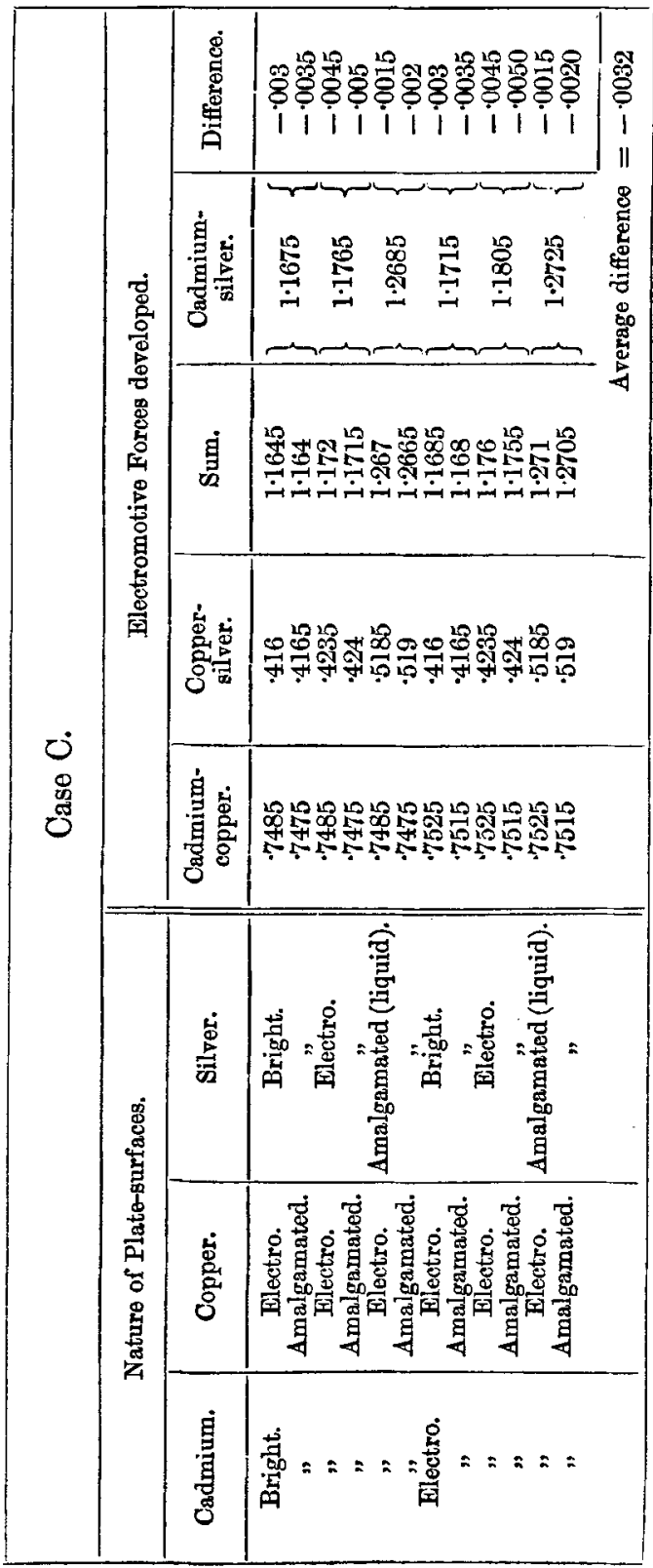




$$
\begin{aligned}
& \text { Average difference in case A } \ldots . . .=+\cdot 0042
\end{aligned}
$$

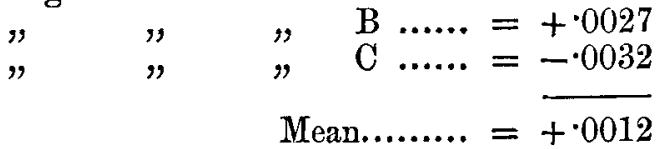

On carrying out twin-cell experiments like those described in $\S 122$, it was found that when a silver plate was placed in the central beaker, and either copper and zinc, copper and cadmium, or zinc and cadmium plates were used in the other beakers, together with solutions of the respective metallic sulphates of the same molecular strengths, the difference between the electromotive forces determined in the twin cell was always sensibly equal to the E.M.F. developed by the pair of plates other than silver employed when taken out and opposed to each other in an ordinary cell containing the same metallic solutions; and this was found to be the case, not only with freshly-prepared plates, but also with plates that had been immersed for hours and had become oxidized on the surface. For instance, in a pair of experiments with amalgamated zinc, bright silver, and electro-copper plates:-

\section{Cells newly set up.}

Zinc-copper in single cell . . $1 \cdot 115$

Copper-silver in twin cell . $\cdot 417$

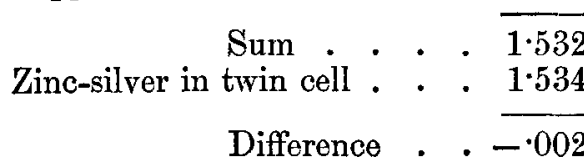

After 24 hours.

$1 \cdot 098$

$\cdot 425$

1.522

$+\cdot 001$

Similar results were obtained in several other experiments of the same kind, both with zinc-copper plates opposed to silver and with the other two pairs (zinc-cadmium and cadmium-copper). The average difference in each case was considerably less than $\pm \cdot 001$ volt.

Relations between the Electromotive Forces of Zinc-Silver, Copper-Silver, and Cadmium-Silver Cells and those corresponding to the net Chemical Actions taking place therein.

129. In all the cells hitherto examined in this series of researches there has been shown to be a sensible equality between the electromotive forces generated with clean platesurfaces of pure metals and those corresponding to the net chemical and physical actions taking place therein. A priori, 
there does not seem to be any evident reason why the same state of things should not exist in the case of cells containing silver plates. 'Thomsen's thermo-chemical valuations, however, indicate that the electromotive forces corresponding to the three equations

$$
\begin{aligned}
& \mathrm{Zn}+\mathrm{Ag}_{2} \mathrm{SO}_{4}=2 \mathrm{Ag}+\mathrm{ZnSO}_{4}, \\
& \mathrm{Cd}+\mathrm{Ag}_{2} \mathrm{SO}_{4}=2 \mathrm{Ag}+\mathrm{CdSO}_{4}, \\
& \mathrm{Cu}+\mathrm{Ag}_{4} \mathrm{SO}_{4}=2 \mathrm{Ag}+\mathrm{CuSO}_{4},
\end{aligned}
$$

are considerably higher than those actually observed and tabulated above, thus:-

Zinc-silver.

$\mathrm{Zn}, \mathrm{O}, \mathrm{SO}_{3}$ aq. $=106090$

$\mathrm{Ag}_{2}, \mathrm{O}, \mathrm{SO}_{2}$ aq. $=20390$

$\left.\begin{array}{c}\text { Diff., per gramme- } \\ \text { molecule } \ldots . . . . . . .\end{array}\right\} \overline{85700}$

Diff., per gramme-
equivalent......... $\overline{42850}$

Corresponding to volt 1.890
Cadmium-silver.

$\mathrm{Cd}, \mathrm{O}, \mathrm{SO}_{\mathrm{a}} \mathrm{aq} .=89500$

$\mathrm{Ag}_{2}, \mathrm{O}, \mathrm{SO}_{3}$ aq. $=20390$

$\overline{69110}$

$\overline{34555}$
Copper-silver.

$\mathrm{Cu}, \mathrm{O}, \mathrm{SO}_{3}$ aq. $=55960$

$\mathrm{Ag}_{2}, \mathrm{O}, \mathrm{SO}_{3}$ aq. $=20390$

35570

In each of the three cases the calculated E.M.F. is from $\cdot 34$ to 37 volt above the observed values when silver plates not amalgamated are used, indicating that even when only infinitesimal currents are generated a large amount of energy is nonadjuvant. It will be shown in a future paper that this behaviour is more or less marked in other kinds of cells containing silver plates and silver compounds, although the minimum amount of nonadjuvancy observed in any given case is variable with the nature of the saline compounds in the cell *. In order to see whether the rise in E.M.F. produced by amalgamating the silver plate is due simply to the heat of formation of silver sulphate being less when the silver is dissolved in mercury than when it is free, determinations of the heat of solution of silver (precipitated from the nitrate by copper, crystalline) were made. It was found a littlo difficult to get every trace of silver used dissolved in mercury when 20 grams of silver and 600 of mercury were employed, even though the surface of the former was washed with dilute nitric acid. With smaller amounts of mercury only incomplete solution was

* Raoult has already obtained numbers (Ann. Chim. et Phys. [4] ii. 317 and iv, 392) indicating that the "galvanic heat" (\$17) of a cell containing copper, silver, and the nitrates of their metals is sensibly below the value due to the net chemical action taking place. These and other similar observations will be discussed in a future paper. 
effected, more or less pasty amalgam being formed, and a smaller heat-development being then noticeable. The most trustworthy determinations made indicated that during the solution of 108 grams of silver, 2070 gramme-degrees are evolved. Hence the heat of formation of silver sulphate, when the silver is dissolved in mercury, is, per gramme-molecule, $20390-2 \times 2070=16250$; so that the heat of displacement of silver from silver sulphate, when the metal is ultimately obtained in mercurial solution, is greater than the values above calculated for zinc, cadmium, and copper respectively as precipitating metals by 4140 gramme-degrees per gramme-molecule, or 2070 per gramme-equivalent, corresponding with $\cdot 0915$ volt. The average difference in E.M.F. between cells otherwise alike, in which crystalline electro-silver and amalgamated silver (fluid) are respectively used, is almost identical with this, being $\cdot 101-\cdot 008=\cdot 093$ volt. As already noticed $(\$ 120)$, silver and cadmium differ in their behaviour in this connexion when amalgamated, the inequality between the effect on the E.M.F. actually produced by amalgamation of cadmium and that corresponding with the heat of solution in mercury being probably due to the oxidation of cadmium by dissolved air.

Rate of Fall in Electromotive Force through so-called " Polarization" for definite Amount of Increase in Rate of Currentflow.

130. In order to see whether the electromotive forces of the cells above described are rendered less (when no current passes) than they otherwise would be, through the interfering action of dissolved air or some other similar obscure cause, a number of experiments were made like those described in Part V. ( $\$ \S 103-105)$, with the general result of showing that the deficiency observed in the E.M.F. actually generated when no current passes (as compared with that calculated from the thermo-chemical data) is at any rate not due to any such cause, inasmuch as the E.M.F. generated when a current does pass is always more or less below that set up when no current passes, just as with normal Daniell cells and with the zinccadmium and cadmium-copper cells above described. Thus, for example, the following numbers were obtained in three experiments, in each of which bright zinc plates were employed, and one in which electro-copper plates were used, the silver plates being in each instance uppermost and surrounded by saturated silver sulphate solution. 


\begin{tabular}{|c|c|c|c|c|}
\hline $\begin{array}{l}\text { Fluid surrounding } \\
\text { the zine plates. } \\
\text { Fluid surrounding } \\
\text { the copper plates }\end{array}$ & $\begin{array}{c}\text { Zinc-sulphate solu- } \\
\text { tion, sp. gr. 1.42. } \\
\ldots \ldots\end{array}$ & $\begin{array}{c}\text { Zinc-sulphate solu- } \\
\text { tion, sp. gr. } 1.42 . \\
\ldots \ldots\end{array}$ & $\begin{array}{c}\text { Zine-sulphate solu- } \\
\text { tion, sp. gr. } 1 \cdot 10 \\
\ldots . .\end{array}$ & $\left\{\begin{array}{l}\text { Copper sulphate } \\
\text { sol., sp. gr. 1.17. }\end{array}\right.$ \\
\hline $\begin{array}{l}\text { Nature of silver } \\
\text { plates. }\end{array}$ & $\begin{array}{l}\text { Electro-silver (cry- } \\
\text { stalline. }\end{array}$ & $\begin{array}{l}\text { Solid crystallized } \\
\text { amalgam. }\end{array}$ & $\begin{array}{l}\text { Solid crystallized } \\
\text { amalgam. }\end{array}$ & $\begin{array}{l}\text { Electro-silver (cry- } \\
\text { stalline). }\end{array}$ \\
\hline $\begin{array}{l}\text { Resistance, in } \\
\text { ohms, of column } \\
\text { of fluid between } \\
\text { plates ................ } \\
\text { Maximum E.M.F. }\end{array}$ & $\begin{array}{l}66.9 \\
1 \cdot 500\end{array}$ & $\begin{array}{l}76.0 \\
1.511\end{array}$ & $\begin{array}{l}76 \cdot 6 \\
1.546\end{array}$ & $\begin{array}{l}71 \cdot 0 \\
.401\end{array}$ \\
\hline $\begin{array}{l}\text { Current-density, } \\
\text { in mieroampères. }\end{array}$ & \multicolumn{4}{|c|}{ Observed amounts of fall in Electromotive Force. } \\
\hline $\begin{array}{r}20 \\
50 \\
100 \\
200 \\
400 \\
600 \\
1000 \\
2000\end{array}$ & $\begin{array}{l}.016 \\
.025 \\
.041 \\
.062 \\
.080 \\
.116 \\
.209\end{array}$ & $\begin{array}{l}.010 \\
.018 \\
.036 \\
.067 \\
.097 \\
.144 \\
.258\end{array}$ & $\begin{array}{l}.012 \\
.021 \\
.026 \\
.037 \\
.059 \\
.077 \\
\cdot 112 \\
\cdot 177\end{array}$ & $\begin{array}{l}.005 \\
.011 \\
.019 \\
.030 \\
.047 \\
.063\end{array}$ \\
\hline
\end{tabular}

These numbers are represented graphically by the curves marked respectively V., VI., VII., and VIII. in the figure.

On trying experiments, like those described in $\$ 110$, to see how far the falling-off in E.M.F. when a current is generated could be due to the accumulation of zinc (cadmium or copper) sulphate round the plate opposed to the silver, it was found that the maximum possible effect due to this cause could not exceed about $\cdot 04$ volt with zinc and cadmium, and 02 with copper. These experiments, and others of a similar nature, will be discussed in a future paper.

On comparing the eight curves represented in the figure with those previously described as obtained with various forms of Daniell cell (Part V. §105), it is noticeable, first, that the curves obtained with the zinc-cadmium cells underlie all the others (I., II., and III.); secondly, that the curve with the cadmium-copper cell (IV.) is practically identical with one of the Daniell-cell curves-indicating consequently that, whilst the substitution of copper for cadmium in a zinc-cadmium cell raises the position of the curve (i.e. increases the rate of fall in E.M.F. according as the current-density increases), the substitution of cadmium for zine in a Daniell cell does not materially alter the position of the curve; thirdly, the curves with the zinc-silver and copper-silver cells overlie all the others, whilst the copper-silver curve (VIII.) is not widely different from the zinc-silver curves (V., VI., and VII.)indicating that, whilst the substitution of silver for copper in a 
Daniell cell largely raises the position of the curve, the effect of substituting copper for zinc in a zinc-silver cell is very much less marked. In other words, the nature of the dissolved metal affects the rate of decrease in E.M.F. with increasing cur'rentdensity much less than does the nature of the deposited metal; whilst the less the heat of formation of the salt of the latter that is decomposed by the passage of the current, the more rapid appears to be the rate of fall in the E.M.F. of the cell as the current-density increases. As regards the first part of this general conclusion, it is precisely what also results from the majority of the previously described experiments on the effect of halving the area of the dissolved plate, as compared with that produced by halving the area of the plate on which metal is deposited. The following experiments with cells containing silver plates also give the same general results.

Effect of Varying the Size of one of the Plates in Cells containing Silver as one of the Metals, the other Plate remaining unaltered.

131. By operating in the way described in $\S 115$, the following results were obtained in four sets of observations with zinc-silver and copper-silver cells, showing that, in all cases, halving the area of the silver plate produces a sensibly greater decrease in the E.M.F. set up with a constant rate of currentflow than is effected by halving the area of the plate opposed to the silver.

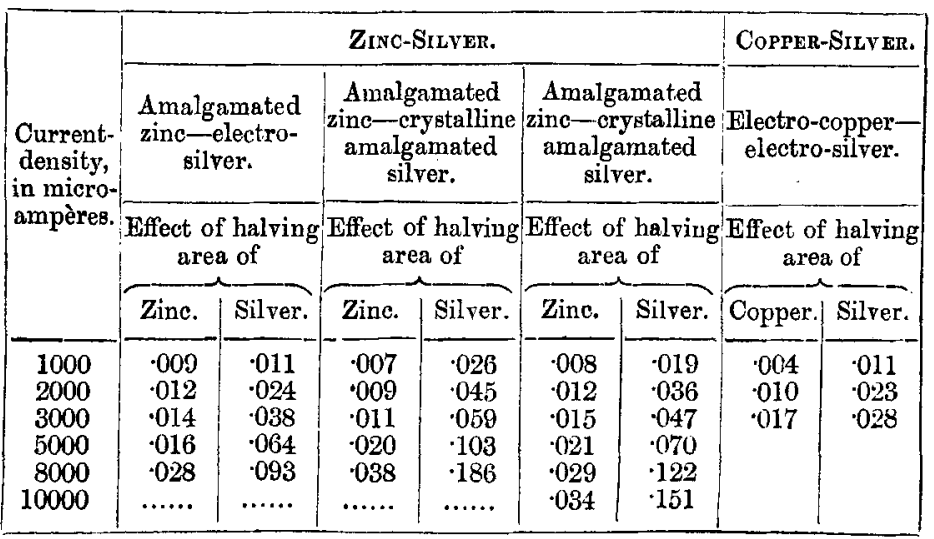

Sumnary of Results.

132. The foregoing results may be thus summarized :-

Cells containing zinc and cadmium or cadmium and copper Phil. Mag. S. 5. Vol. 14. No. 87. Sept. 1882. P 
plates, immersed in solutions of the sulphates of these metals respectively, are closely analogous to ordinary Daniell cells (containing zine sulphate solution). Slight variations in the E.M.F. generated are introduced by varying the condition of the plate-surfaces; but in all cases the maximum E.M.F. actually generated with clean pure plate-surfaces and with solutions of equal molecular strengths is close to that calculable from the net chemical action taking place in the cell when generating a current. When the cadmium plates are not amalgamated, or are covered with crystalline solid amalgam, the electromotive forces are close to .75 and -36 volt for cadmium-copper and zinc-cadmium cells respectively, the values corresponding to the net chemical actions as deduced from Thomsen's thermo-chemical results being substantially the same. When the cadmium plates are covered with fluid amalgam, the electromotive forces are lower in the first case and higher in the second by upwards of $\cdot 04$ volt-a quantity distinctly exceeding in magnitude the E.M.F. corresponding with the heat of solution of cadmium in mercury, although of the same sign.

(2) The electromotive forces of zinc-silver, cadmium-silver, and copper-silver cells containing the respective sulphates of these metals differ from those of zinc-cadmium, zinc-copper (Daniell), and cadmium-copper cells in this respect, that the maximum electromotive forces generated (the fluids being of equal molecular strength) are not sensibly the same as those calculated from Julius Thomsen's thermal data, but in every case fall short by an amount not far from $\cdot 35$ volt. When the silver plates are not mercurialized, or are coated with crystalline amalgam, the electromotive forces (which vary slightly with the precise nature of the plate-surfaces) are, in the three cases, near to $1.53,1.17$, and 0.42 volt respectively, the metallic solutions being of equal molecular strength. 'When the silver plates are covered with fluid amalgam, the electromotive forces are in each case about $\cdot 09$ volt higher than the values obtained with electro-deposited crystalline metal, this increase almost exactly coinciding with the increment corresponding with the heat of solution of silver in mercury.

(3) As long as the cadmium and zinc [or copper] solutions employed are of the same molecular strength within the limits indicated respectively by $\mathrm{MSO}_{4} 50 \mathrm{H}_{2} \mathrm{O}$ and $\mathrm{MSO}_{4} 1250 \mathrm{H}_{2} \mathrm{O}$, the E.M.F. developed with a given pair of cadmium and zinc [or copper] plates is sensibly independent of the actual strength of the solutions, these cells behaving precisely like Daniell cells in this respect. With Daniell cells the solutions are practically of the same molecular strength when they 
are of the same specific gravity; but with the other cells containing cadmium this is not so, cadmium-sulphate solution being uniformly more dense than either zine or copper solution of the same molecular strength.

(4) The effect on the E.M.F. of a cell of a given alteration in the nature of the surface of either a zinc, copper, cadmium, or silver plate is sensibly the same numerically whichever other one of these four metals be opposed to it; but the direction of the alteration is opposite according as the plate is the anode or the kathode of the combination.

(5) Volta's "Law of Summation" universally holds within the limits of experimental error in all the cases examined; that is, the electromotive forces of zinc-cadmium, cadmiumcopper, and copper-silver combinations are such that, for any given kinds of plate-surfaces, the sums of the two first, of the two last, and of the three together are respectively equal to the electromotive forces of zinc-copper, cadmium-silver, and zinc-silver combinations.

(6) Zinc, copper, and cadmium plates alter superficially (probably in consequence of oxidation by dissolved air) more rapidly when opposed to silver than when opposed to any other one of these four metals, on being immersed in solutions of their respective sulphates forming one half of a cell on Daniell's principle-no current being generated by the cell, the measurements being made by means of a quadrant electrometer.

(7) With all the cells examined the behaviour when generating a current is analogous to that of a normal Daniell cell: when the current-density exceeds a few microampères per square centimetre of plate-surface, a more or less marked diminution in the E.M.F. ensues, the falling-off being the greater the greater the current-density. With moderately strong currents the diminution far exceeds the maximum possible amount due to accumulation of dissolved salt round the plate dissolved, and exhaustion of solution round the other plate. Cateris paribus, the rate of fall in E.M.F. as the current-density increases is the more rapid the lower the heat of formation of the metallic salt decomposed in tie cell so as to deposit the metal, and is comparatively but little affected by the nature of the dissolved metal.

(8) The effect of halving the area of the plate on which metal is deposited is usually to cause a greater diminution in the E.M.F. than is produced by halving the area of the dissolved plate; amalgamated cadmium plates in zinc-cadmium cells, however, form an exception to this rule. 